\title{
Chinese reform pushes R\&D into market
}

[BEIJING] In a major reform of its public sector research system, the Chinese government has decided to convert into self-supporting enterprises 242 research institutes that now operate under ten government agencies.

The institutes "will go to market," says an official from the Ministry of Science and Technology. He adds that the government's goal is to push the institutes closer to industry, in the belief that this will increase the flexibility and vigour of public research and development (R\&D), and speed up the application of research results in industry.

The institutes — with a payroll of 173,000 employees, including nearly 47,000 retired - will be free to choose their research and commercial strategies, according to a paper from the science ministry. But they will be strongly encouraged to become technological enterprises that can carry out R\&D in addition to business activities.

The agencies include the bureaux of the coal, mechanics, metallurgical, textile and petroleum/chemical industries, as well as the bureaux of light industry and internal trade. Many were formerly ministry-level government agencies. In future, they will fall under the State Economic and Trade Commission, a powerful agency which reports to the State Council, China's central government.

The State Council has approved the reform plan, submitted by the science ministry and 11 other ministries. The institutes will be expected to operate on the new basis from 1 July. During a transition period, the State Economic and Trade Commission and the ten national administration bureaux will be responsible for routine management.

The science ministry spokesman denies that the government is taking this action because the institutes run inefficiently. Apart from a few, he says, most of the institutes are efficient and productive. "They have long learned to survive in the market," he says. "Indeed, 90 per cent of their revenues come from the market. So I don't think they will be greatly influenced.”

But Sun Chuanyao, president of Beijing

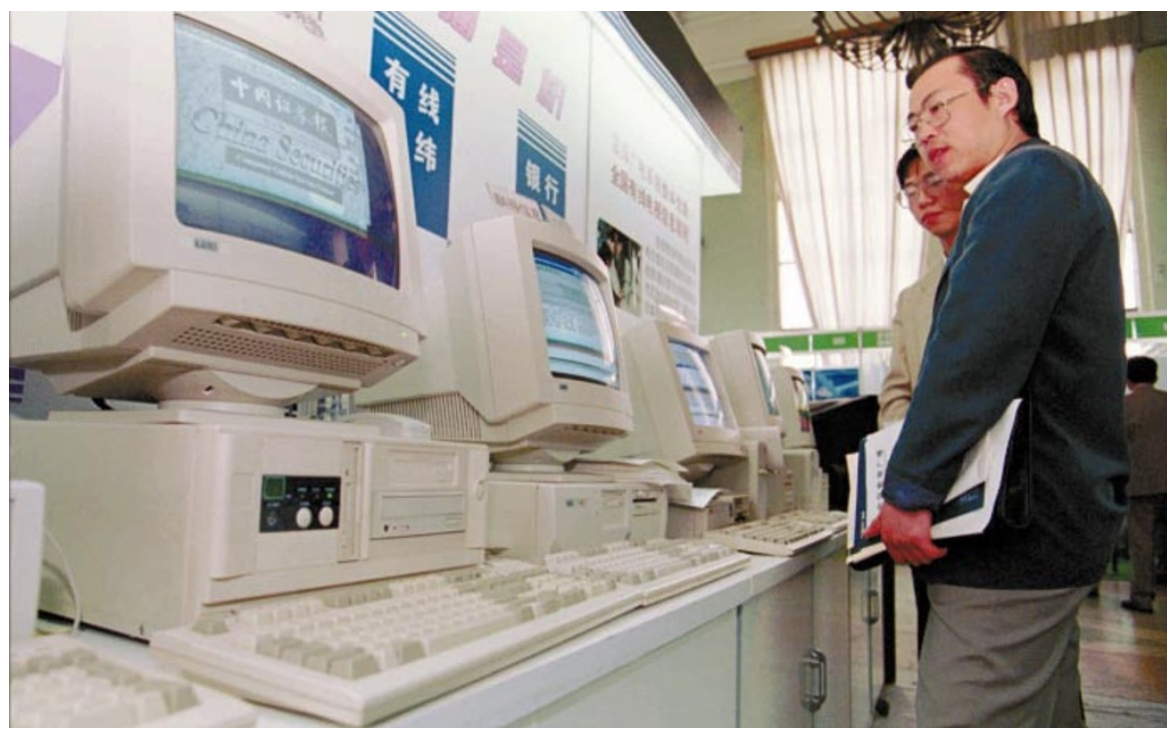

Research in action: visitors at Chinese computer exhibition consider the latest equipment.

General Research Institute of Mining and Metallurgy (BGRIMM), is worried.

"After this reform, no one may be prepared to do work which is less lucrative, but which the state really needs," says Sun. "Certain research activities will have to be cancelled, and some institutes may not be able to survive as research organizations."

On becoming enterprises, says Sun, the institutes may find it hard to maintain a balance between earning money and carrying out fundamental research. "China is not short of enterprises, but most of the stateowned enterprises are debt-ridden. Socalled 'technological enterprises' should avoid taking the path that they followed."

But he does not think the reform threatens his own institute. "We have been marketbased for a long time, and have been in close relations with industry; this is our difference from the Chinese Academy of Sciences."

BGRIMM has a strong record. Its slurry electrolysis technology and its emulsified explosives for mining are world famous.

In 1997, the General Research Institute for Non-ferrous Metals (GRINM) drew a

\section{Japan's fast-breeder loses money fast too}

[токуо] Japan's Nuclear Fuel Cycle Development Organization (JNC) has built up a consolidated deficit of more than $¥ 1.6$ trillion (US $\$ 13$ billion), says a finance report released last week by the government's Management and Coordination Agency.

The report says that JNC's losses are largely due to the high cost of research and development work at Monju, the experimental fast-breeder reactor. The programme has faced increasing public opposition after an accident at Monju in
December 1995 (see Nature 387, 646; 1995 \& 389,653 ; 1997).

JNC, formerly the Power Nuclear Fuel Development Corporation, has received $¥ 2.4$ trillion from the government since 1996. Yet the value of its assets - mainly land and property — is currently only $¥ 850$ billion.

The Management and Coordination Agency is now warning that JNC's research needs to be closely evaluated if it is to justify any future funding for the fastbreeder programme.
Asako Saegusa 400-millimetre long mono-crystal silicon line, 300 millimetres in diameter. The United States, Japan and Germany are the only other countries to have mastered this technique. In collaboration with other institutes, GRINM also produced China's first high-temperature superconductor cable made of materials from the bismuth series.

The government now faces the task of ensuring that institutes such as BGRIMM and GRINM remain creative and productive. "The government hopes that industrial enterprises will play a major role in China's R\&D efforts, but such enterprises are far from that goal," says a BGRIMM researcher.

Although a few research institutes will be allowed to keep their government-supported status, they will have to operate like private companies. Administratively, they will be responsible to local government.

The research institutes involved in this reform will enjoy special privileges. They will continue to receive some operating funds from the government, although this is intended primarily to support those who have already retired. For the first five years they will be exempt from enterprise income tax, operating tax based on revenues from transferring technology, and property taxes on urban land used for R\&D purposes.

The new bodies will have the same rights as remaining government research institutions when bidding for governmentfinanced research programmes. Research programmes already approved by the government will be conducted according to the original arrangements.

"This is only the first step," says the ministry official. "The second step will begin immediately after this, when 400 or more research institutes under different ministries will be involved."
Tian Xuewen 